\title{
Quality Management amongst South African Agribusiness Firms: The Role of ISO 9000 Quality Assurance Standards
}

\section{R Turner and G F Ortmann}

School of Agricultural Sciences and Agribusiness, University of Natal, Pietermaritzburg

\section{ABSTRACT}

Worldwide, the ISO 9000 quality assurance standards have received considerable support from firms seeking to improve their competitiveness. A postal survey was conducted amongst 92 South African agribusiness firms to determine the extent of the adoption of ISO 9000 , reasons for certification and to identify the costs and benefits of adopting these standards. About 36 percent of the respondent firms were certified. The desire to improve customer service, a basis for quality improvement and the need to improve operational efficiency were the most important factors influencing certification. Respondents reported financial, managerial and production benefits following certification. Broadly speaking, certified firms operate as private or public companies, have parent company affiliations, are involved in manufacturing, and are established firms with large annual turnovers.

JEL Q13

\section{INTRODUCTION}

Due to changes in both the local and international policy and economic environments, South African agribusiness firms are faced with increasing competition in both domestic and international markets. To be competitive, firms need to respond to customer demands and at the same time become more cost effective relative to competitors. Thus, to succeed in a highly competitive environment, firms have to improve product and service quality, whilst at the same time reduce production and transaction costs. A strategy that firms can use to achieve these objectives is to adopt internationally recognised quality standards, including the ISO 9000 quality assurance standards.

The purpose of this paper is to present some important results of a postal survey conducted amongst South African agribusiness firms. The objectives of the 
postal survey were to determine the extent of adoption of the ISO 9000 quality assurance standards, the reasons for certification and to identify the costs and benefits of adopting these standards. The questionnaire also investigates the orientation of agribusiness firms to other quality systems, namely Hazard Analysis Critical Control Point (HACCP) and Total Quality Management (TQM).

\section{ISO 9000, HACCP and TQM}

In 1987, the Geneva-based International Organisation for Standardisation (ISO) published a series of quality assurance standards which were collectively known as ISO 9000 . The ISO 9000 series consists of five standards, ISO 9000-9004, of which ISO 9001-9003 list the certification requirements for quality systems of variable comprehensiveness, decreasing from ISO 9001 to 9003 (Schiefer, 1994). The ISO 9000 standards are voluntary principles of good practice and have been adopted by the European Union and much of the industrialised world (Schiefer, 1994; Schuler et al., 1996). At the end of 1997, over 226000 certifications had been awarded in 129 countries worldwide, of these South Africa holds 1915 certificates (ISO, 1998). Europe (excluding United Kingdom), the United Kingdom, Far East Countries and North America held 39, 25, 14 and 11 percent of these certifications respectively. The standards represent a quality assurance system, not a product certification scheme (Schuler et al., 1996). According to Hendry (1991), the system aims primarily at preventing nonconformity at all production stages, from design through to servicing. The objective of the ISO 9000 series is to promote worldwide standards which will improve quality, operating productivity and efficiency, and reduce costs (Schuler et al., 1996). To achieve ISO certification, a company must obtain the guidelines (from a certifying body), adapt them to its own particular needs, prepare documentation, train employees, follow the documentation procedures and submit to an audit by an external registration organisation which is accredited by the ISO standards organisation. Continuous monitoring and verification of the quality management system ensures that the system does not deteriorate. Surveillance audits are conducted by third-party auditors usually every six months with a full reassessment every three years.

The key objective of the HACCP principles is to ensure food safety, particularly the control of chemical, microbiological and physical hazards (Caswell \& Hooker, 1996). Bredahl and Holleran (1997) report that greater food safety legislation is forcing food companies to adopt risk management tools, such as the HACCP principles. An effective HACCP system will identify key (critical) points along the processing chain where potential hazards are likely to occur, implement preventive measures to contain hazards and establish monitoring 
procedures (Caswell \& Hooker, 1996; Unnevehr \& Jensen, 1996). Faced with sanitary and phytosanitary regulations (non-tariff barriers), food companies applying HACCP principles will be at a competitive advantage (Caswell \& Hooker, 1996).

According to Develin and Hand (1993), TQM is a system of behaviour which encompasses everyone within an organisation and determines their relationships with the outside world. Tingey (1997) reports that TQM is a comprehensive set of management tools, management philosophies and improvement methods which include customer orientation, the empowerment of employees, management participation and continual process improvement. The focal point of TQM is the customer, and every aspect of an organisation centres on satisfying the needs of the customer (Schuler et al., 1996).

\section{STUDY METHODOLOGY}

Agribusiness firms in the context of this study include agricultural input suppliers (seed, feed, fertiliser, agrochemical, equipment and machinery manufacturers), agricultural output processors (wineries, tanneries, canneries, dairies, textiles, sugar and grain millers, sawmills, abattoirs and other farm product processors), as well as agricultural service providers (fruit exporters, pack-houses, agricultural retail suppliers). Since no mailing list of agribusiness firms in South Africa is available, all means to locate these firms (e.g. telephone directories, mailing lists from relevant associations, magazines, South African Bureau of Standards (SABS) register (1998)) were used. A mailing list of 280 South African agribusiness firms was assembled in this way.

A questionnaire was compiled, based on the work by Bredahl and Holleran (1997) and SABS (1995). A pilot survey was conducted during March 1998 amongst four agribusiness firms, two of which were ISO 9000 certified. From constructive feedback, possible problems and misunderstandings regarding certain questions were identified and rectified. A postal survey was conducted during July and August 1998. Owing to generally poor responses to postal surveys, the whole population of agribusiness firms (280) was surveyed in an attempt to ensure sufficient responses for statistically valid results. Written reminders were sent to firms which had not responded after one month and these firms were also contacted telephonically.

From the 280 questionnaires sent out, 44 percent (124) of questionnaires were returned. Of these, only 92 questionnaires were usable whilst 32 non-usable responses were received from companies not willing to participate in the study. The usable response rate of 32,9 percent for a postal survey can be regarded as 
satisfactory. Van der Wiele and Brown (1997), Manchester Business School (1996), Scicchitano (1996) and a South African study (SABS, 1995) reported response rates of $32,28,26$ and 36 percent for their respective postal surveys.

\section{GENERAL CHARACTERISTICS OF RESPONDENTS}

This section deals with the characteristics of the sample of South African agribusiness firms that responded to the questionnaire. The characteristics include ISO 9000 certification status, types of business arrangement, firm size, financial aspects and export orientation.

\subsection{ISO 9000 certification}

In this study 35,9 percent of the sample firms $(n=92)$ indicated they were ISO 9000 certified. Of these 33 firms, 94 percent (31) were certified in the ISO 9002 model with the remaining two firms being ISO 9001 certified. The ISO 9001 model is the most comprehensive in the series (covers 20 elements: quality assurance in design/development, production, installation and servicing) whilst ISO 9002 contains 18 elements (excludes design/development considerations) (Schuler et al., 1996). Of the remaining respondent firms $(\mathrm{n}=59), 15$ percent (9) were "intermediate" whilst 85 percent $(50)$ were not certified. Intermediate firms had initiated ISO 9000 implementation but were not certified at the time of the survey. In the remainder of this paper, ISO 9000 certified firms are referred to as "certified" firms, whilst firms which had initiated ISO 9000 implementation and firms which were not certified are referred to as "intermediate" and "noncertified" firms respectively.

\subsection{Nature of business}

The majority of respondents ( 84 percent) are involved in manufacturing, with 16 percent being involved in the service sector. Manufacturing includes processing firms. Service firms include retailers, importer/distributors, brokers, consultants, exporters and research, development and marketing firms. Manufacturing comprised 94 percent of certified firms compared with 78 percent of intermediate and non-certified firms respectively.

When asked about the type of products or services their firm produces/provides, a wide spectrum of products/services were listed (21 categories in all). To facilitate data analysis it was necessary to reclassify the products/services into three broad classes. Table 1 describes the three classes and which products/services each supplies. 
Table 1 Classification of products and services among a sample of South African (SA) agribusiness firms, $1998(n=92)$

\begin{tabular}{|l|l|c|c|c|c|}
\hline $\begin{array}{l}\text { Class } \\
\text { descrip- } \\
\text { tion }\end{array}$ & Products/Services & n & $\begin{array}{c}\text { Percen- } \\
\text { tage } \\
\text { certified } \\
\text { firms }\end{array}$ & $\begin{array}{c}\text { Percen- } \\
\text { tage inter- } \\
\text { mediate } \\
\text { frms }\end{array}$ & $\begin{array}{c}\text { Percen- } \\
\text { tage non- } \\
\text { certified } \\
\text { frms }\end{array}$ \\
\hline $\begin{array}{l}\text { Products } \\
\text { derived } \\
\text { from } \\
\text { agricultur } \\
\text { al output }\end{array}$ & $\begin{array}{l}\text { dairy, maize, sugar, } \\
\text { poultry and fruit products } \\
\text { etc., textiles, canned fruit, } \\
\text { foodstuffs, timber, } \\
\text { tea/coffee, wine and } \\
\text { spirits, hides and skins }\end{array}$ & 46 & 45,7 & 8,6 & 45,7 \\
\hline $\begin{array}{l}\text { Products } \\
\text { used as } \\
\text { agricultur } \\
\text { al inputs }\end{array}$ & $\begin{array}{l}\text { fertiliser, agricultural } \\
\text { machinery and equip- } \\
\text { ment, feed manufacturers, } \\
\text { agrochemicals, seed } \\
\text { producers and feed } \\
\text { premixes }\end{array}$ & 40 & 30 & 7,5 & 62,5 \\
\hline $\begin{array}{l}\text { Agricul- } \\
\text { tural } \\
\text { service } \\
\text { providers }\end{array}$ & $\begin{array}{l}\text { buying and selling of } \\
\text { agricultural products, } \\
\text { property marketing, } \\
\text { consultants, exporters, } \\
\text { agricultural retail } \\
\text { suppliers }\end{array}$ & 6 & 0 & 66,7 & 33,3 \\
\hline
\end{tabular}

* Intermediate firms had initiated ISO 9000 implementation but were not certified at the time of the survey.

Forty-six percent of products derived from agricultural output and 30 percent of products used as agricultural inputs originated from certified firms. Although the ISO 9000 quality assurance standards had not yet been adopted by any of the service agribusiness firms in this study, they can be adapted to any type of business (Schuler et al., 1996). Of the six firms in this class, four (67 percent) are currently implementing ISO 9000.

The average age of agribusiness firms in the sample was 38 years 5 months (median $=30$ years). The lower median age suggests that a few older firms skew the distribution. The mean age of certified, intermediate and non-certified firms are 55 years 3 months $($ median $=50$ years), 17 years 8 months (median $=12$ years) and 30 years 4 month (median $=24$ years) respectively. The difference in mean age between certified and non-certified firms (24 years 11 months) is statistically significant at the one percent level of probability. 


\subsection{Business arrangements}

The most common business arrangement among respondent agribusiness firms $(n=92)$ was the private company ( 67 percent), followed by the public company ( 25 percent) and the cooperative ( 4 percent), with the remaining three firms being individually owned, a partnership and a close corporation. Of the sample certified firms (33), 70 percent operate as private companies, 27 percent as public companies, with a partnership making up the remaining three percent. Intermediate firms (9) comprise private companies ( 78 percent) and public companies (22 percent). The majority of non-certified firms are private companies (64 percent), 24 percent public companies and cooperatives ( 8 percent). The close corporation (1) and individual ownership (1) were also represented.

Of the total respondents, 75 percent had parent company affiliation, of which 73,5 percent were South African parent companies. A greater proportion of certified firms had parent company affiliation ( 91 percent) compared to intermediate ( 67 percent) and non-certified firms ( 66 percent), with 72 percent of certified firms, 67 percent of intermediate and 76 percent of non-certified firms having South African parent companies.

\subsection{Export orientation of respondent firms}

Of all the respondents 79 percent are involved in the export market. About 82 percent of certified and 89 percent of intermediate companies export their products compared to 76 percent of non-certified firms. Table 2 summaries the proportion of physical production sold on the export market and turnover derived from exports.

The mean proportion of physical products sold on the export market and turnover derived from exports are higher for certified than non-certified firms. The mean turnover from exports $(n=53)$ amounts to $R 126,7$ million whilst the median value is considerably less (R16,5 million). Mean turnover from exports for certified firms $(n=19)$ equals $R$ 100,9 million (median $=R 35$ million) which is lower than the R528,5 million (median $=\mathrm{R} 106,3$ million) of intermediate firms $(n=6)$ but higher than that of non-certified firms $(n=28)$ which amounts to $\mathrm{R} 58,2$ million (median $=\mathrm{R} 7,6$ million). 
Table 2 Proportion of production sold as, and turnover derived from, exports of a sample of SA agribusiness firms, 1998

\begin{tabular}{|l|c|c|c|c|}
\hline All firms & $\begin{array}{c}\text { Certified } \\
\text { firms }\end{array}$ & $\begin{array}{c}\text { Intermediate } \\
\text { firms }\end{array}$ & $\begin{array}{c}\text { Non-certified } \\
\text { firms }\end{array}$ \\
\hline \multicolumn{5}{|c|}{ Proportion of physical products sold on export market (percent) } \\
\hline Mean & $26,6(\mathrm{n}=65)$ & $25,1(\mathrm{n}=23)$ & $54,8(\mathrm{n}=8)$ & $20,9(\mathrm{n}=34)$ \\
\hline Median & 10 & 10 & 60 & 15 \\
\hline Range & $0,5-100$ & $1-100$ & $1-100$ & $0,5-90$ \\
\hline Proportion of turnover from exports (percent) \\
\hline Mean & $23,2(\mathrm{n}=62)$ & $21,7(\mathrm{n}=21)$ & $40,7(\mathrm{n}=8)$ & $19,9(\mathrm{n}=33)$ \\
\hline Median & 10 & 6 & 25 & 12 \\
\hline Range & $0,55-100$ & $1-100$ & $5-100$ & $0,55-96$ \\
\hline
\end{tabular}

When considering the destination of exports, the majority of exports $(54,2$ percent) were destined for the African continent, with Europe $(25,1$ percent) and Asia (10,4 percent) being other significant markets. Table 3 summarises the export destinations of exporting firms in the study.

When comparing certified and non-certified firms, some broad conclusions can be made. Relatively speaking, exporting to Australasia and Asia has a positive influence on certification. Exporting to Africa does not necessitate certification but, interestingly enough, results suggest that this is also true for Europe. As the ISO 9000 standards originated in Europe and have received considerable support there, this result seems contrary to expectations. The result might be explained by the fact that alternative (substitute) quality assurance systems are in place in non-certified firms and at present these satisfy European customer requirements. However, there may be increasing pressure on non-certified firms to adopt the ISO 9000 standards as the future demand for such standards increases among importing countries. 
Table 3 Percentage of total exports to various continents, sample of SA agribusiness firms, 1998.

\begin{tabular}{|c|c|c|c|c|c|c|}
\hline Continent & Africa & Europe & Asia & $\begin{array}{c}\text { Austra- } \\
\text { lasia }\end{array}$ & $\begin{array}{c}\text { North } \\
\text { America }\end{array}$ & $\begin{array}{c}\text { South } \\
\text { America }\end{array}$ \\
\hline \multicolumn{7}{|c|}{ All companies $(n=67)$} \\
\hline Mean & 54,2 & 25,1 & 10,4 & 5,2 & 3,1 & 2,0 \\
\hline Median & 70 & 2 & 0 & 0 & 0 & 0 \\
\hline Range & $0-100$ & $0-100$ & $0-90$ & $0-100$ & $0-32$ & $0-27$ \\
\hline \multicolumn{7}{|c|}{ Certified firms $(n=23)$} \\
\hline Mean & 50,6 & 16,0 & 17,0 & 10,4 & 3,5 & 2,5 \\
\hline Median & 60 & 0 & 8 & 0 & 0 & 0 \\
\hline Range & $0-100$ & $0-100$ & $0-90$ & $0-100$ & $0-32$ & $0-27$ \\
\hline \multicolumn{7}{|c|}{ Intermediate firms $(n=8)$} \\
\hline Mean & 50,3 & 33,4 & 9,2 & 0 & 7,0 & 0,1 \\
\hline Median & 49,8 & 14,5 & 0,5 & 0 & 2,5 & 0 \\
\hline Range & $0-100$ & $0-88$ & $0-30$ & 0 & $0-30$ & $0-0,68$ \\
\hline \multicolumn{7}{|c|}{ Non-certified firms $(n=36)$} \\
\hline Mean & 57,4 & 29,1 & 6,4 & 3,0 & 2,1 & 2,0 \\
\hline Median & 88,5 & 7,8 & 0 & 0 & 0 & 0 \\
\hline Range & $0-100$ & $0-100$ & $0-60$ & $0-90$ & $0-27$ & $0-26$ \\
\hline
\end{tabular}

\subsection{Firm size and financial position}

Firm size was measured according to two factors, namely firm turnover (gross sales) and number of employees. Table 4 summarises the annual turnover and number of employees of respondent agribusiness firms. The total number of people employed by these firms was 77963 people. The total turnover of respondent agribusiness firms $(n=72)$ was $R 26,4$ billion.

Comparing mean and median values, both turnover and employee numbers were higher for certified than non-certified firms. The mean difference in annual turnover between certified and non-certified companies (R329,131 million) is statistically significant at the five percent level of probability. 
Table 4 Annual turnover and number of employees, sample of SA agribusiness firms, 1998.

\begin{tabular}{|l|l|l|l|l|}
\hline \multicolumn{1}{|c|}{ All firms } & Certified firms & $\begin{array}{l}\text { Intermediate } \\
\text { firms }\end{array}$ & $\begin{array}{l}\text { Non-certified } \\
\text { firms }\end{array}$ \\
\hline Annual turnover (R million) & $\begin{array}{l}541,885 \\
(\mathrm{n}=24)\end{array}$ & $\begin{array}{l}665,721 \\
(\mathrm{n}=7)\end{array}$ & $\begin{array}{l}212,754 \\
(\mathrm{n}=41)\end{array}$ \\
\hline Mean & $\begin{array}{l}366,503 \\
(\mathrm{n}=72)\end{array}$ & 336,4 & 110,0 \\
\hline Median & 199,0 & 477,5 & $4,5-2429,0$ & $2,5-1093,6$ \\
\hline Range & $2,5-2429,0$ & $10-2337,4$ & & $736(\mathrm{n}=50)$ \\
\hline Number of employees & \multicolumn{5}{|l}{} \\
\hline Mean & $847(\mathrm{n}=92)$ & $1155(\mathrm{n}=33)$ & $339(\mathrm{n}=9)$ & 190 \\
\hline Median & 223 & 420 & 200 & $12-10000$ \\
\hline Range & $9-10000$ & $9-8000$ & $10-1100$ &
\end{tabular}

To determine the financial position of the agribusiness firms, they were asked to supply their current and net capital ratios (Table 5). The current ratio (current assets/current liabilities) indicates business liquidity whilst the net capital ratio (total assets/total liabilities) measures firm solvency.

Table 5 Current and net capital ratios, sample of sample SA agribusiness firms, 1998.

\begin{tabular}{|l|c|c|c|c|}
\hline & All firms & Certified firms & $\begin{array}{c}\text { Intermediate } \\
\text { firms }\end{array}$ & $\begin{array}{c}\text { Non-certified } \\
\text { firms }\end{array}$ \\
\hline Current ratio \\
\hline Mean & $1,93(\mathrm{n}=44)$ & $1,67(\mathrm{n}=15)$ & $1,38(\mathrm{n}=4)$ & $2,17(\mathrm{n}=25)$ \\
\hline Median & 1,57 & 1,44 & 1,16 & 2,05 \\
\hline Range & $0,43-6,50$ & $0,9-3,61$ & $1-2,20$ & $0,43-6,50$ \\
\hline Net capital ratio & \multicolumn{5}{|l}{} \\
\hline Mean & $2,79(\mathrm{n}=42)$ & $2,95(\mathrm{n}=15)$ & $1,49(\mathrm{n}=3)$ & $2,86(\mathrm{n}=24)$ \\
\hline Median & 1,72 & 1,80 & 1,38 & 1,63 \\
\hline Range & $0,19-10,00$ & $1,32-8,82$ & $1,22-1,87$ & $0,19-10,00$ \\
\hline
\end{tabular}

Given the favourable liquidity situation of non-certified companies, if the decision was made to adopt the ISO 9000 standards, these firms should be in a position to meet the associated costs involved. The presence of a substitute 
quality assurance system could explain why these firms are not certified at present. This aspect will be discussed in the next section.

\section{QUALITY CONTROL AND SUPPLIER RELATIONSHIP}

When asked if their firm had a system to address deviations from quality specifications, 92 percent of respondents $(n=92)$ indicated they had a system in place. In all, ISO 9000 was mentioned in 46 percent of cases, which is higher than the reported certified companies ( 36 percent) as some companies are in the process of implementing ISO 9000 . All certified companies $(n=33)$ had systems in place (sometimes in combination with HACCP or in-house quality assurance systems), but interestingly enough 86 percent of non-certified companies $(n=50)$ reported using some form of quality assurance system(s). These include: in-house quality assurance systems ( 71,5 percent), conformance with external standards (19 percent) and HACCP (9,5 percent). Half of the intermediate firms mentioned ISO 9000 , in-house quality assurance systems were reported by the remaining firms. In this category no mention was made of HACCP. In-house quality assurance systems are those systems which are developed and monitored internally whilst external standards are stipulated by external bodies (government specifications, veterinary and medical regulations, etc.).

The mean age of respondent firms' $(n=79)$ current quality control system(s) is 103 months ( 8 years 7 months), but more important is the difference in age between certified, intermediate and non-certified firms' current quality control system(s). The mean age of quality control system(s) for certified firms is 53 months (4 years 5 months) compared to 13 years 6 months and 10 years 11 months for intermediate and non-certified firms respectively.

Of the respondent firms, 84 percent indicated that their employees receive quality control training, whilst 89 percent said that training was continuous. All employees of certified companies receive quality control training (intermediate firms $=87,5$ percent) compared with 73,5 percent of non-certified firms, with 94 percent of employees of the former receiving continuous training (intermediate firms $=100$ percent) compared to 82 percent of the latter. About 88 percent of certified and 80 percent of non-certified firms indicated that their customers require the presence of a quality assurance system.

Of 89 respondent firms, at present only 45 percent require their suppliers to have a quality assurance system in place, whilst the majority ( 77 percent) said it would be a future requirement. Presently, only 42 percent of certified and 44 percent of intermediate firms required suppliers to have a quality assurance 
system compared to 47 percent of non-certified firms, but in the future 75 percent of certified, 89 percent of intermediate and 76 percent of non-certified companies would make it a requirement. When asked which quality assurance system would be a future requirement, ISO 9000 was mentioned by 70 percent of certified respondents $(n=23)$. With intermediate companies $(n=7)$, ISO 9000 was mentioned in 71 percent of responses. The main quality assurance systems mentioned by non-certified companies $(n=31)$ included ISO 9000 (29 percent) and customised systems ( 26 percent), with 13 percent of respondents being unsure. A greater proportion of certified ( 73 percent) and intermediate companies ( 78 percent) work with suppliers on quality assurance compared to 64 percent of non-certified firms.

When asked about the single most important reason for adopting a quality assurance system, 41 percent of respondents $(n=91)$ cited firm-driven or internal reasons (improved operational efficiency, cost reduction, etc.), whilst 54 percent indicated customer-driven or external reasons (gain market share, customer requirement, etc.). About six percent cited a combination of both firm/customer-driven reasons. Most certified companies (51,5 percent) cited firm-driven reasons compared to 56 and 61 percent of intermediate and noncertified firms which reported customer-driven reasons.

When questioned if the adoption of a quality assurance system was standard business practice for a firm in its line of business, 63 percent $(n=92)$ indicated that locally it was standard business practice whilst 88,5 percent $(n=87)$ felt that it was standard business practice in the international arena. In the questionnaire, standard business practice was defined as "widely accepted by sectoral participants (i.e. producers, buyers, sellers and regulators)". Interestingly, only 58 percent of certified companies (intermediate firms $=56$ percent, non-certified firms $=68$ percent) felt that the adoption of a quality assurance system was a standard business practice locally, whilst 81 percent (intermediate firms $=100$ percent, non-certified firms $=91,5$ percent) thought it was an international standard business practice.

Of the total respondents $(n=92), 55$ percent can be classified as agri-food firms. When asked about their familiarity with HACCP, 72 percent of the agri-food respondents were familiar with this concept. Of the certified $(n=19)$ and intermediate $(n=7)$ agri-food companies, 84 and 71 percent were familiar with HACCP compared to 62,5 percent of non-certified agri-food firms $(n=24)$. Of the agri-food respondents, 52 percent had adopted HACCP principles whilst 44 percent thought that HACCP is commonly adopted in their respective lines of business. About 63 percent of the certified agri-food companies had implemented HACCP compared to 46 percent of non-certified agri-food firms. Of the certified agri-food firms, 68 percent felt $\mathrm{HACCP}$ is applicable to a firm in 
their line of business whilst only 25 percent of non-certified agri-food firms held the same view. These results suggest that certified agri-food companies are more aware of and concerned with quality issues and more likely to adopt systems to address these issues, for example HACCP. In addition, the results support the findings of Early and Shepherd (1997: 395) that HACCP and ISO 9000 are compatible. As ISO 9000 is not a product quality system, incorporating HACCP principles into a ISO 9000 system would satisfy food safety requirements.

Of all the respondents $(n=92), 75$ percent indicated it was not difficult to identify input suppliers whilst 25 percent sometimes had difficulty in identifying suppliers. When asked if it is relatively time-consuming to draft supply specifications, 52 percent of respondents answered no, whilst 35 percent indicated it was sometimes time-consuming and 13 percent said that it was timeconsuming. A greater proportion of certified companies (21 percent) fall into the "time-consuming" bracket as compared to non-certified companies (6 percent). Only 12 percent of certified companies indicated that searching for a supplier is a frequent monthly activity as compared to 16 percent of non-certified companies (intermediate firms $=25$ percent). A greater proportion of certified $(45,5$ percent) and intermediate $(62,5$ percent) firms had over 50 suppliers to choose from compared to non-certified firms ( 30 percent).

The percentage of certified companies that inspect a supplier's product before signing a contract ( 91 percent) was greater than the 70 percent of non-certified companies (intermediate firms $=89$ percent). Most certified companies (67 percent) negotiate long-term contracts with suppliers compared to only 54 percent of non-certified firms (intermediate firms $=89$ percent). The fact that certified companies find it time-consuming to draft supply specifications, inspect products before signing contracts and work with suppliers on quality assurance is consistent with the finding that certified companies are more likely to negotiate long-term contracts and therefore reduce the frequency of searching for input suppliers.

Of the respondents $(n=92), 63$ percent have farmers as suppliers. Fewer certified firms ( 58 percent) have farmers as suppliers as opposed to non-certified companies (62 percent). The inputs (products) supplied by farmers are presented in Table 6. 
Table 6 Input (product) supplied by farmers to a sample of SA agribusiness firms, 1998

\begin{tabular}{|l|c|c|c|c|c|c|c|c|}
\hline & \multicolumn{2}{|c|}{ All firms } & \multicolumn{2}{c|}{$\begin{array}{c}\text { Certified } \\
\text { firms }\end{array}$} & \multicolumn{2}{c|}{$\begin{array}{c}\text { Inter- } \\
\text { mediate } \\
\text { firms }\end{array}$} & \multicolumn{2}{c|}{$\begin{array}{c}\text { Non- } \\
\text { certified } \\
\text { firms }\end{array}$} \\
\hline Input (product) & $\mathbf{n}$ & $\%$ & $\mathbf{n}$ & $\%$ & $\mathbf{n}$ & $\%$ & $\mathbf{n}$ & $\%$ \\
\hline Milk & 7 & 12,3 & 6 & 86 & 1 & 14 & 0 & 0 \\
\hline $\begin{array}{l}\text { Grains and other } \\
\text { crops }\end{array}$ & 19 & 33,3 & 4 & 21 & 3 & 16 & 12 & 63 \\
\hline Sugar-cane & 7 & 12,3 & 5 & 71 & 0 & 0 & 2 & 29 \\
\hline Fruit and vegetables & 6 & 10,4 & 1 & 17 & 1 & 17 & 4 & 66 \\
\hline Chickens & 2 & 3,5 & 0 & 0 & 0 & 0 & 2 & 100 \\
\hline $\begin{array}{l}\text { Animal products } \\
\text { and grains }\end{array}$ & 3 & 5,3 & 0 & 0 & 1 & 33 & 2 & 67 \\
\hline Timber & 3 & 5,3 & 0 & 0 & 0 & 0 & 3 & 100 \\
\hline Seed & 3 & 5,3 & 0 & 0 & 1 & 33 & 2 & 67 \\
\hline Wine/grapes & 2 & 3,5 & 1 & 50 & 0 & 0 & 1 & 50 \\
\hline Animal products & 3 & 5,3 & 1 & 33 & 0 & 0 & 2 & 67 \\
\hline Fruit and wine & 2 & 3,5 & 1 & 50 & 1 & 50 & 0 & 0 \\
\hline TOTAL & 57 & 100 & & 19 & & 8 & & 30 \\
\hline
\end{tabular}

From Table 6 it is clear that given the same input (product), some companies have adopted ISO 9000 while others have not. This may indicate that there exists scope for these non-certified companies to go the ISO 9000 route too. The incidence of certification is much higher amongst firms using milk and sugar cane inputs. As yet, no companies sourcing seed, timber, chickens and combined animal/grain inputs have sought certification.

Of the firms having farmers as suppliers, 93 percent indicated that they required minimum quality standards from farmers. More certified companies (95 percent) required minimum standards from their farmers than non-certified companies (90 percent). All intermediate firms required minimum quality assurance standards from their farmers. Considering the vertical supply chain concept (i.e. raw material supplier (farmer) $\rightarrow$ processor $\rightarrow$ retailer), respondent firms were asked if they thought the incorporation of quality control measures at farm level could make the supply chain more productive and cost-efficient. Almost all certified companies ( 95 percent) answered yes whilst 87,5 percent of intermediate and 79 percent of non-certified companies agreed. Firms were asked if they thought the ISO 9000 quality assurance standards could facilitate 
such control measures. The majority (67 percent) of certified companies said yes, with equal proportions of the remaining respondents ( 33 percent) answering no and uncertain. Of the non-certified firms, 28 percent, 31 percent and 41 percent responded with yes, no and uncertain respectively.

\section{ISO 9000 CERTIFICATION}

\subsection{General characteristics of firms}

Although one firm gained ISO 9000 certification in 1988, 76 percent of all certifications $(n=33)$ occurred during the last five years. Of the certified respondents, 76 percent hold their certification with the SABS, 12 percent with SGS whilst the remaining four firms (12 percent) hold certification with the following certification bodies: Dekra, EQnet and DQS, DAR and Lloyds. The majority of certified firms were introduced to the ISO 9000 quality assurance standards by their company headquarters ( 55 percent), with clients and the SABS accounting for 13 percent each. The remaining 19 percent comprises media ( 6 percent), competitors ( 3 percent) and other ( 10 percent).

Just over a quarter of respondents (26 percent) indicated it was necessary to hire a consultant to assist with documentation, while the majority (74 percent) said it was not necessary to do so. When implementing a quality assurance system, an organisation may utilise internal resources, outside consultants, or a combination of both (Guerin \& Rice, 1996). If internal resources are employed, a quality assurance supervisor or administrator has to be appointed, working full-time up to two years. According to Hendry (1991), departmental managers can expect to spend about 20 percent of their time for two years on ISO 9000 implementation. In addition, at least 24 hours training per employee is required. If time is an important factor, then a consultant could be commissioned to assist in implementing ISO 9000 and keep teething problems to a minimum. Consultants can assist with the process of organisation, documentation and meeting the ISO 9000 quality assurance standards. It is important to see the consultants' client lists to determine how much experience they have had with ISO 9000 and with similar companies. The mean number of pre-certification audits among respondents was 1,621 (median $=1)$. One firm achieved certification with no pre-certification audits whilst one firm needed six.

Certified firms were also asked whether they considered ISO 9000 certification to be a standard business practice for a firm in their line of business in terms of time (presently and in the future) and scope (locally and internationally). About 64 percent felt certification to be a standard business practice locally at present, while 90 percent felt it would be a standard business practice locally in the 
future. On the other hand, about 78 percent of respondents felt certification was a standard business practice internationally at present, but all respondents indicated it would be a standard business practice internationally in the future.

\subsection{Factors which motivated ISO 9000 certification}

When asked to give the single most important reason for adopting the ISO 9000 quality assurance standards, 42 percent of certified firms $(n=33)$ cited internal firm-driven reasons, 42 percent reported external customer-driven reasons whilst 16 percent indicated a combination of the two. Internal factors include procedural efficiency, staff motivation, and reductions in error rates, wastage and costs, whilst external reasons include customer requirements and the desire to gain market access and market share. From their British study, Bredahl and Holleran (1997) report that firms become ISO 9000 certified for both internal (firm-driven) and external (customer-driven) reasons - internal reasons accounted for 52 percent of ISO 9000 certifications, 36 percent related to external reasons and the remaining 12 percent were influenced by both factors. Of the certified respondents in this study $(\mathrm{n}=33), 61$ percent indicated that their principal customers did not require certification at present, but 78 percent of certified firms thought that certification would be a future customer requirement. This point reinforces the fact that the external or customer-driven reason for certification is not the main driving force at present, but in the future it may become the dominant reason.

To investigate the motivating factors in more detail, certified respondent firms were asked to indicate the importance of these factors on a three-category scale ranging from "not important" to "important" and "very important". The proportion of firms which indicated "important" or "very important" for each influencing factor is given in Table 7 . The factors were ranked according to these proportions.

Table 7 Factors which motivated ISO 9000 certification among a sample of SA agribusiness firms, $1998(n=32)$

\begin{tabular}{|l|c|c|c|}
\hline Factor & Mode" & $\begin{array}{c}\text { Percentage of firms } \\
\text { indicating } \\
\text { "important" or } \\
\text { "very important" }\end{array}$ & Rank \\
\hline Improved customer service & 3 & 100 & 1 \\
\hline A basis for quality improvement & 3 & 96,9 & 2 \\
\hline $\begin{array}{l}\text { Improved operational efficiency } \\
\text { (reduce wastage) }\end{array}$ & 3 & 90,7 & 3 \\
\hline
\end{tabular}




\section{Table 7 continued}

\begin{tabular}{|l|c|c|c|}
\hline Factor & Mode* & $\begin{array}{c}\text { Percentage of firms } \\
\text { indicating } \\
\text { important" or } \\
\text { very important" }\end{array}$ & Rank \\
\hline Access to foreign markets & 3 & 87,5 & 4 \\
\hline Reduction in operating costs & 2 & 87,5 & 4 \\
\hline Gain market share & 3 & 84,4 & 6 \\
\hline Customer requirement & 2 & 84,4 & 6 \\
\hline Unite various quality systems & 2 & 81,3 & 8 \\
\hline $\begin{array}{l}\text { Certification will be a future } \\
\text { requirement }\end{array}$ & 3 & 80,7 & 9 \\
\hline $\begin{array}{l}\text { Industry requirement (stay in } \\
\text { business) }\end{array}$ & 2 & 75,0 & 10 \\
\hline Corporate mandate & 2 & 67,7 & 11 \\
\hline Reduction in transaction costs & 2 & 56,3 & 12 \\
\hline Other (n=2) & & & \\
\hline
\end{tabular}

* where $1=$ not important, $2=$ important and $3=$ very important

The desire to improve customer service was the most influential factor, followed by a basis for quality improvement and the desire to improve operational efficiency (reduce wastage). Although the importance of certification in reducing transaction costs was only ranked twelfth, it is evident from other factors (such as improved customer service, improved operational efficiency, access to foreign markets, certification being a future requirement and uniting various quality systems) that it is an important motivating factor.

The following additional factors that motivated certification were raised by two firms: a) to ensure uniformity between plants, b) retain existing customers, c) improve utilisation of facilities, d) improve skills, knowledge, attitude and ability and e) clear transmission of information. The respondents rated each of these five factors as being very important.

Zaibet and Bredahl (1997) believe that the main motivating factors for firms to become ISO certified include: a) coordinating operations in different plants, b) improving internal communication, $c$ ) enhancing the firm's competitive position (maintain or increase market share) and d) increasing firm efficiency by improving food safety whilst reducing total costs. According to Guerin and Rice (1996: 27), companies seek ISO 9000 registration for a number of reasons, 
which include customer pressure, quality benefits, market advantage and EU regulation requirements. Van der Wiele and Brown (1997: 300) cite the following driving forces of ISO certification: Market related factors, customer service, quality and efficiency improvement, and as a "kick start" for quality improvement. A South African study (SABS, 1995) ranked the reasons for becoming certified as follows: a) the desire to improve existing management systems, b) to gain competitive/market advantage and c) realising the value of becoming certified (improve management and production efficiency, and financial retums).

\subsection{Impact of ISO 9000 certification}

Respondents were asked to score on a five-point scale, ranging from 1 (highly negative) to 5 (highly positive), the impact of certification on each performance indicator. The ranking of performance indicators was based on the proportion of respondents indicating a "positive" or "highly positive" impact (Table 8).

Table 8 Rating of performance indicators, sample of SA agribusiness firms, 1998

\begin{tabular}{|l|c|c|c|}
\hline Performance Indicator & Mode* & $\begin{array}{c}\text { Percentage of firms } \\
\text { indicating } \\
\text { "positive" or } \\
\text { "highly positive" }\end{array}$ & Rank \\
\hline $\begin{array}{l}\text { Documented process (e.g. record- } \\
\text { keeping) }(\mathrm{n}=32)\end{array}$ & 5 & 96,9 & 1 \\
\hline Overall firm performance $(\mathrm{n}=32)$ & 4 & 93,8 & 2 \\
\hline Quality of output $(\mathrm{n}=32)$ & 4 & 93,7 & 3 \\
\hline Error rates (decrease) $(\mathrm{n}=32)$ & 4 & 90,6 & 4 \\
\hline Customer service $(\mathrm{n}=31)$ & 4 & 90,4 & 5 \\
\hline Quality of purchased inputs $(\mathrm{n}=32)$ & 4 & 81,3 & 6 \\
\hline Competitiveness $(\mathrm{n}=32)$ & 4 & 75,0 & 7 \\
\hline Sales $(\mathrm{n}=31)$ & 4 & 74,2 & 8 \\
\hline Inter-firm communication $(\mathrm{n}=32)$ & 4 & 71,9 & 9 \\
\hline Productivity $(\mathrm{n}=32)$ & 4 & 71,9 & 9 \\
\hline $\begin{array}{l}\text { Worker satisfaction } / \text { employee } \\
\text { morale }(\mathrm{n}=32)\end{array}$ & 4 & 68,8 & 11 \\
\hline Market access $(\mathrm{n}=32)$ & 4 & 68,8 & 11 \\
\hline
\end{tabular}


Table 8 continued

\begin{tabular}{|l|c|c|c|}
\hline Performance Indicator & Mode* & $\begin{array}{c}\text { Percentage of firms } \\
\text { indicating } \\
\text { "positive" or } \\
\text { "highly positive" }\end{array}$ & Rank \\
\hline $\begin{array}{l}\text { Wastage ( i.e. scrap costs) (decrease) } \\
(\mathrm{n}=32)\end{array}$ & 4 & 68,8 & 11 \\
\hline Profits ( $\mathrm{n}=32)$ & 4 & 68,7 & 14 \\
\hline $\begin{array}{l}\text { Overall operating costs (decrease) (n } \\
=32)\end{array}$ & 4 & 65,6 & 15 \\
\hline Market share ( $\mathrm{n}=32)$ & 4 & 56,3 & 16 \\
\hline
\end{tabular}

*where $1=$ highly negative impact, $3=$ no impact and $5=$ highly positive impact

Certification had a positive impact on most performance indicators, in particular on documented processes (e.g. record-keeping), overall firm performance and quality of output. In addition, certification has had a positive impact on reducing error rates, customer service and quality of purchased inputs. Factors ranked 1, $5,6,9$ and 11 show the positive impact of certification on reducing transaction costs. Similar findings have been reported by Market and Opinion Research International (1996), Manchester Business School (1996), Hendry (1991), SABS (1995) and Zaibet and Bredahl (1997).

Certified firms were asked to provide information (before and after certification) of any improvements in performance measures resulting from certification. A summary of the certified companies' experiences is shown in Table 9.

Clearly, substantial benefits have been achieved from certification. Substantial cost savings can be achieved through improvements in conformance to specifications, less reject products/returns and scrap material, and less customer complaints will ensure continued customer satisfaction and support. Improvements in certain performance measures (indicated by an asterisk in Table 9) are expected to lead to lower transaction costs. 
Table 9 Actual improvements in performance measures as reported by a sample of ISO 9000 certifled firms, $1998(n=19)$

\begin{tabular}{|c|c|c|c|}
\hline Improvement & $\mathbf{n}$ & Before certification & After certification \\
\hline $\begin{array}{l}\text { Conformance to } \\
\text { specifications* }\end{array}$ & 10 & \multicolumn{2}{|c|}{$\begin{array}{l}\text { Mean improvement }=15,9 \text { percent }(n=8), \\
\text { range }=5-25 \text { percent }\end{array}$} \\
\hline Problem solving & 1 & $\begin{array}{l}\text { Problems were not } \\
\text { followed up }\end{array}$ & $\begin{array}{l}\text { Problems solved } \\
\text { much faster }\end{array}$ \\
\hline Management & 1 & $\begin{array}{l}\text { Management were not } \\
\text { so quality conscious }\end{array}$ & $\begin{array}{l}\text { Management totally } \\
\text { involved }\end{array}$ \\
\hline $\begin{array}{l}\text { Less customer } \\
\text { complaints* }\end{array}$ & 4 & \multicolumn{2}{|c|}{$\begin{array}{l}\text { Mean improvement }=394 \text { percent }(n=2) \\
\text { range }=188-600 \text { percent }\end{array}$} \\
\hline $\begin{array}{l}\text { Reduced product } \\
\text { returns/rejects* }\end{array}$ & 4 & \multicolumn{2}{|c|}{$\begin{array}{l}\text { Mean improvement }=314 \text { percent, } \\
\text { range }=91-666 \text { percent }\end{array}$} \\
\hline $\begin{array}{l}\text { Suppliers }{ }^{*} \text { input } \\
\text { conformance* }\end{array}$ & 2 & $85 \%(n=1)$ & $95 \%(n=1)$ \\
\hline $\begin{array}{l}\text { Documentation } \\
\text { efficiency* }\end{array}$ & 1 & \multicolumn{2}{|l|}{ Overall improvement } \\
\hline Calibration* & 2 & \multicolumn{2}{|c|}{$\begin{array}{l}\text { Mean improvement }=48 \text { percent } \\
\text { range }=47-49 \%\end{array}$} \\
\hline Employee discipline & 1 & \multicolumn{2}{|c|}{ Overall improvement } \\
\hline Scrap material* & 1 & $2,0 \%$ of final product & $1,3 \%$ of final product \\
\hline Product losses & 1 & $\pm R 700000$ per annum & $\begin{array}{l} \pm \mathrm{R} 400000 \mathrm{pa} \text { after } \\
1,5 \text { years }\end{array}$ \\
\hline Corrective action & 1 & $\begin{array}{l}\text { Haphazard corrective } \\
\text { action }\end{array}$ & $\begin{array}{l}\text { Standardised } \\
\text { corrective action } \\
\text { system }\end{array}$ \\
\hline $\begin{array}{l}\text { Penalties due to non- } \\
\text { conformance* }\end{array}$ & 1 & R45514 & 0 \\
\hline
\end{tabular}

* improvements which reduce transaction costs

\subsection{Costs of ISO 9000 certification}

Certified firms were asked to estimate the costs of ISO 9000 implementation, pre-certification auditing fees and ISO certification (Table 10). All costs shown in Table 10 are expressed on a 1997/98 basis and have been classified according to firm turnover to account for firm size. ISO 9000 implementation costs include items such as staff training, documentation procedures, hiring of consultants, redeployment of internal resources and the acquisition of equipment for 
calibration. Certification costs depend upon firm size, complexity (nature of processes) and the ISO 9000 series chosen.

Table 10 Costs of ISO 9000 certification among a sample of SA agribusiness firms, $1997 / 98=100$.

\begin{tabular}{|l|c|c|c|c|c|}
\hline Costs of ISO 9000 & Group * & $\mathbf{n}$ & Mean (R) & $\begin{array}{c}\text { Median } \\
\text { (R) }\end{array}$ & Range (R) \\
\hline Implementation & A & 7 & 56256 & 50943 & $11880-154957$ \\
& B & 6 & 144228 & 100101 & $14200-300000$ \\
& C & 6 & 302949 & 146711 & $50943-1045440$ \\
\hline Pre-certification & A & 5 & 8046 & 7642 & $5043-11880$ \\
auditing fees & B & 3 & 8070 & 4632 & $1500-18078$ \\
& C & 7 & 24901 & 10189 & $6113-70296$ \\
\hline Certification & A & 4 & 8235 & 7301 & $6457-11880$ \\
& B & 3 & 27704 & 21300 & $15496-46316$ \\
& C & 6 & 39883 & 24453 & $7030-99792$ \\
\hline Total cost & A & 6 & 67541 & 50934 & $12000-167871$ \\
& B & 6 & 162115 & 136975 & $14200-322826$ \\
& C & 7 & 318758 & 163019 & $19911-1188000$ \\
\hline Total cost per & A & 6 & 664,04 & 522,00 & $198,00-1554,36$ \\
employee & B & 6 & 453,77 & 137,30 & $14,35-2137,92$ \\
& C & 6 & 583,27 & 399,24 & $20,17-1321,35$ \\
\cline { 4 - 6 } & & Percent & Percent & Percent \\
\hline Total cost as a & A & 6 & 0,301 & 0,157 & $0,027-1,024$ \\
percentage of & B & 6 & 0,041 & 0,048 & $0,003-0,065$ \\
turnover & C & 6 & 0,045 & 0,019 & $0,011-0,140$ \\
\hline
\end{tabular}

* Group $A=$ company turnover $<$ R 100 million

Group $B=$ company turnover $\geq R 100$ million but $<R 650$ million Group $\mathrm{C}=$ company turnover $\geq \mathrm{R} 650$ million

To account for firm size, total costs of certification are expressed as a percentage of annual turnover and total certification costs per employee. Zaibet and Bredahl (1997) reported that the total cost of achieving ISO 9000 certification did not exceed 1,5 percent (range $=0,07-1,5$ percent) of turnover of four firms in their United Kingdom meat sector study. They concluded that these costs should not represent a constraint toward achieving certification. The results of this study suggest that the costs of certification may be prohibitive for very small firms, as smaller firms show the highest cost per Rand of turnover and per employee. There is also some evidence of diseconomies for very large firms. However, the means computed for the largest firms were skewed by one firm that reported 
certification costs in excess of R1 million (this firm achieved ISO 9001 certification). The median values presented in Table 10 indicate size economies across the full range of turnover, but higher certification costs per employee for very small and very large firms.

Of the ISO 9000 certified firms ( $n=33$ ), 88 percent indicated that the benefits of ISO 9000 certification outweigh the costs incurred. Of these 29 firms, 79 percent said benefits significantly outweighed the costs whilst 21 percent reported small net benefits. Of the certified firms, 97 percent believed that adopting the ISO 9000 quality assurance standards could benefit South African agribusiness firms. Being an importer and distributor of agricultural equipment, the remaining firm felt that as long as overseas suppliers were certified, local certification was not necessary.

\subsection{Disadvantages of ISO 9000 certification}

When asked to list any disadvantages of ISO 9000 certification, some 85 percent of certified firms related their experiences. Nearly 40 percent of respondents (n $=28$ ) indicated there were no disadvantages/drawbacks of certification, while cost considerations were mentioned by 10.5 percent of respondents. Excessive documentation load/paperwork was mentioned in 25 percent of cases. Other drawbacks mentioned also reflect the following disadvantages of ISO 9000 reported in other studies (Sadgrove, 1995; van der Wiele and Brown, 1997): a) it is bureaucratic, b) excessive ongoing paperwork, c) it is internally focused (internal processes), d) staff feel that standards are imposed on them, and e) ISO 9000 does not encourage continuous process improvement.

\subsection{ISO 9000 and TQM}

After a brief introduction of the Total Quality Management (TQM) concept, 58 percent of the certified firms indicated they had adopted the principles of TQM. Of the certified firms that had not adopted TQM $(n=14), 43$ percent had considered and rejected TQM, and an equal percentage was currently considering implementing TQM, while 14 percent had never come across the concept.

ISO 9000 and TQM are not equivalent, but ISO 9000 forms part of the quality management process. The ISO 9000 and TQM approaches have both similarities and differences. Management responsibility, corrective/preventive action and training are common objectives in both cases. However, ISO 9000 does not totally encompass the TQM principles of continuous quality improvement, customer focus and the training and empowerment (human management) of workers (Fowler \& Lord, 1995; Yung, 1997). Unlike ISO 9000, TQM does not 
place sufficient emphasis on documentation (Yung, 1997). According to Schiefer (1997), to meet continuous quality improvement, a TQM programme has to be integrated into an organisational structure which allows for its documentation, enforcement and control. The ISO 9000 quality assurance standards can provide this necessary structure (Schiefer, 1997; Schuler et al., 1996). Sadgrove (1995:107) added that "without ISO 9000, a TQM company often lacks a systematic approach to quality". Whilst TQM focuses on corporate culture, ISO 9000 looks at corporate systems (Sadgrove, 1995). The marketing advantages of ISO 9000 certification and its documentation procedures could enhance a TQM system. According to Yung (1997), the ISO technical committee are trying to revise the ISO 9000 series (Vision 2000) by incorporating some of the principles (quality improvement, management commitment, customer satisfaction) of TQM.

\section{CONCLUSIONS}

An importing finding of this study is that the majority of sampled South African agribusiness firms are aware of the importance of adopting quality assurance standards. Although just over one third of respondents had sought certification, non-certified firms indicated that through monitoring future market and customer requirements, a decision will be taken on the need for certification. Broadly speaking, certified firms can be said to have the following characteristics: a) they operate as private and public companies, b) have parent company affiliation, c) are involved in manufacturing, d) are older established firms, e) have larger annual turnover and f) are more familiar with HACCP. The desire to improve customer service, a basis for quality improvement and the need to improve operational efficiency (reduce wastage) were the most important factors influencing certification. The importance of certification in reducing transaction costs was also evident. Certification had a positive impact on all performance indicators, in particular on documented processes, overall firm performance and quality of output. Results show that certification can yield real benefits (financial, managerial, production) to enhance firm competitiveness, whilst the costs of certification per Rand of turnover are low.

Two additional points need to be considered. Firstly, barriers to trade, which have steadily declined following international trade agreements (through the General Agreement on Tariffs and Trade/World Trade Organisation), could be replaced by non-tariff barriers such as ISO 9000 certification and HACCP (Caswell \& Hooker, 1996). Although at present ISO 9000 certification remains a voluntary standard, it could become a compulsory requirement (standard business practice) in future international trade. The marketing advantages of ISO 9000 certification (securing new customers and gaining market share) would 
then disappear; being certified would only ensure that a firm can trade internationally. Secondly, as more firms in an industry become ISO 9000 certified, the competitive (marketing) advantages to a single certified firm will decrease (Van der Wiele \& Brown, 1997). Although the marketing advantages of ISO 9000 certification would decrease, potential cost savings (management, production and transaction costs) could still be exploited.

Being a relatively new concept, further research on ISO 9000 certification needs to be conducted. Factors that differentiate between certified and non-certified firms need to be determined. By thoroughly identifying and quantifying the costs and benefits of certification, proper feasibility studies can be done. In addition, monitoring the progress of certification amongst South African agribusiness firms would determine the extent of adoption amongst the various firm types and sizes. Comparisons could then be made between different industry sectors and international experiences.

\section{ENDNOTE}

The authors would like to thank the National Research Foundation (NRF) for their financial assistance towards this research. Opinions expressed and conclusions arrived at are those of the authors, and are not necessarily to be attributed to the NRF.

\section{REFERENCES}

1 BREDAHL, M.E. \& HOLLERAN, E. (1997) "Food Safety, Transaction Costs and Institutional Innovation", In: Schiefer, G. and Helbig, R. (eds.), Quality Management and Process Improvement for Competitive Advantage in Agricultural and Food, Proceedings of the $49^{\text {th }}$ seminar of the European Association of Agricultural Economists, University of Bonn (ILB), Germany: 51-67.

2 CASWELL, J.A. \& HOOKER, N.H. (1996) "HACCP as an International Trade Standard", American Journal of Agricultural Economics, 78 (3): $775-9$.

3 DEVELIN, N. \& HAND, M. (1993) Total Quality Management: Breaking Down the Barriers, Institute of Chartered Accountants in England and Wales, London.

4 EARLY, R. \& SHEPHERD, D. (1997) "A Holistic Approach to Quality with Safety in the Food Chain", In: Schiefer, G. and Helbig, R. (eds.), Quality Management and Process Improvement for Competitive Advantage in Agricultural and Food. Proceedings of the $49^{\text {th }}$ seminar of 
the European Association of Agricultural Economists, University of Bonn (ILB), Germany: 391-400.

5 FOWLER, C. \& LORD, B. (1995) "ISO and TQM", Chartered Accountants Journal of New Zealand, 74 (10): 33-8.

6 GUERIN, J.M. \& RICE, R.W. (1996) "Perceptions of Importers in the United Kingdom, Germany, and the Netherlands Regarding the Competitive Advantages of ISO 9000", Forest Products Journal, 46 (4): 27-31.

7 HEMENWAY, C.G. (1996) "Ten Things you should Know about ISO 14000", SABS-Bulletin, 15 (8): 12-14.

8 HENDRY, I. (1991) "Quality Assured: A Stamp for Survival", Pulp and Paper International, 33 (8): 16-23.

9 ISO (1998) The ISO survey of ISO 9000 and ISO 14000 Certificates - The seventh Cycle: up to and including 1997, International Organisation for Standardisation, Online information: http://www.iso.ch.

10 MARKET AND OPINION RESEARCH INTERNATIONAL (1996) "Attitudes of 'Captains of Industry' towards ISO 9000", Survey Commissioned by SGS Yarsley International Certification Services, ISO 9000 News, 5 (6): 12-14." ISO 9000 - Does it work?", Survey commissioned by SGS Yarsley International Certification Services, ISO 9000 News, 5 (6): 4-11.

11 SABS (1995) Marketing Research Study amongst SABS ISO 9000 certified companies, South African Bureau of Standards, Pretoria.

12 SABS (1998) SABS Register, Malnor Ltd, Auckland Park, SA.

13 SADGROVE, K. (1995) Making TQM Work, Kogan Page Ltd, London.

14 SCHIEFER, G. (1994) Quality Management in Agriculture and Food: Management Principles, System Requirements and Development Directions, Report B-94/2, University of Bonn (ILB).

15 SCHIEFER, G. (1997) Total quality management and quality assurance in agriculture and food. In: Schiefer, G. and Helbig, R. (eds.), Quality Management and Process Improvement for Competitive Advantage in Agricultural and Food. Proceedings of the $49^{\text {th }}$ seminar of the European Association of Agricultural Economists, University of Bonn (ILB): 139 56.

16 SCHULER, C., DUNLAP, J. and SCHULER, K. (1996) ISO 9000: Manufacturing, Software, and Service, Delmar Publishers, New York.

17 SCICCHITANO, P. (1996) "Survey Takes Snapshot of ISO 9000 in the USA", ISO 9000 News, 5 (4): 6-9.

18 TINGEY, M.O. (1997), ISO 9000, Malcolm Baldrige and the SEI CMM for Software, Prentice Hall PTR, Upper Saddle River, USA.

19 UNNEVEHR, L.J. \& JENSEN, H.H. (1996) "HACCP as a Regulatory Innovation to Improve Food Safety in the Meat Industry", American Journal of Agricultural Economics, 78 (3): 764-9. 
20 VAN DER WIELE, T. \& BROWN, A. (1997) "ISO 9000 Series Experiences in Small and Medium-sized Enterprises", Total Quality Management, $8(2 / 3)$ : 300-4.

21 YUNG, W.K.C. (1997) "The Values of TQM in the Revised ISO 9000 Quality System", International Journal of Operations and Production Management, 17 (2): 221-30.

22 ZAIBET, L. \& BREDAHL, M. (1997) "Gains from ISO Certification in the UK Meat Sector", Agribusiness: An International Journal, 13 (4): $375-$ 84. 